The submitted manuscript has been authored by a contractor of the U.S Govenment under contract No. DEAC05-960R22464. Accordingly, the U.S. Government retains a nonexclusive, royalty-free license to publish or reproduce the published form of this contribution, or allow others to do so, for U.S. Government purposes."

\title{
DESIGN OF MICROWAVE VITRIFICATION SYSTEMS FOR RADIOACTIVE WASTE*
}

\author{
T. L. White, W. D. Bostick ${ }^{+}$, C. T. Wilson and C. R. Schaich \\ Oak Ridge National Laboratory \\ Oak Ridge, Tennessee 37831-8071 \\ +Oak Ridge K-25 Site \\ Oak Ridge, Tennessee 37831-7274
}

\begin{abstract}
Oak Ridge National Laboratory (ORNL) is involved in the research and development of high-power microwave heating systems for the vitrification of Department of Energy (DOE) radioactive sludges. Design criteria for a continuous microwave vitrification system capable of processing a surrogate filtercake sludge representative of a typical waste-water treatment operation are discussed. A prototype $915-\mathrm{MHz}, 75-\mathrm{kW}$ microwave vitrification system or "microwave melter" is described along with some early experimental results that demonstrate a 4 to 1 volume reduction of a surrogate ORNL filtercake sludge.
\end{abstract}

\section{Introduction}

Most DOE industrial sites operate process waste-water treatment plants that produce large volumes of hazardous or mixed waste sludges. In an overview of DOE mixed waste inventories ${ }^{1}$, the subcategory of "sludges, filtercakes, and residues", generated primarily from waste-water treatment, represented the largest volume of waste that must be treated for compliance with U.S. Environmental Protection Agency (EPA) regulations. The ORNL Process Water Treatment Plant produces a low-level radiologically contaminated water softening sludge typical of many other DOE and private sector facilities. Microwave sintering or vitrification is one of several processing options being considered for this waste. The goal of treatment is to minimize the volume of waste being stored on-site, while producing a stable waste form that may be qualified for eventual off-site disposal ${ }^{2}$.

ORNL has been involved for several years in the research and development of high-power microwave heating systems for vitrification of DOE radioactive sludges. Microwave vitrification of radioactive waste has many advantages over conventional joule-heated melters ${ }^{3}$. Conventional joule heating requires electrodes in direct contact with the waste

*Oak Ridge National Laboratory, managed by Lockheed Martin Energy Research Corp. for the U.S. Department of Energy under contract number DE-AC05-960R22464. 
glass as well as radiant dome heater electrodes exposed to the acid off-gasses. Electrode corrosion can limit the service life of these melters. Microwave vitrification is electrodeless because microwave energy is absorbed directly by the glass. Microwave energy is absorbed by a large class of waste materials commonly found in many low-level waste streams such as fabrics, rubber, concrete, metal powders, oxides, nitrates, sulfates, nonmetallic filtering media, water, carbon, glass and may other dielectric materials. Because microwave energy is absorbed directly, it has the considerable advantage of much higher efficiency and faster temperature control compared to conventional radiant heating. For joule-heating, the entire melter must be brought to a working temperature over a period of several days to avoid cracking the melter refractory insulation. Microwave melters can be brought to temperature in minutes because internal refractory insulation is not required. Microwave power can be transmitted through waveguides from generators that can be located safely outside a radioactive processing area where routine system maintenance can be easily performed. Waveguide windows can effectively isolate the generator from the vitrification cell. Microwave heating is extremely flexible in that a wide range of processing temperatures are available in a single system. Microwave vitrification systems can be designed to be small enough to be mobilized for on-site treatment of radioactive wastes. High temperature microwave waste forms ${ }^{4}$ are refractory materials with no free liquids, particulates, or organics, and they have a high volume reduction compared to conventional grouting technology, as well as low leachability. A microwave vitrification system can be either an "in-drum" system for vitrification in the final storage container $^{5}$, or an "overflow" type melter system ${ }^{6}$ to vitrify the wastes in a dedicated processing chamber. In-drum vitrification of wastes eliminates transferring molten wastes to secondary containers, therefore, wastes with a wide range of viscosities can be produced. Overflow microwave melters are smaller, somewhat simpler to tune, and can fill any suitable container shape. Heating profiles can be custom-tailored for each application by exciting the appropriate microwave field configuration or "mode," choosing the proper heating frequency and material geometry, and understanding how the microwave penetration depth is controlled by temperature and material composition of the waste form.

\section{Continuous Microwave Melter Design Criteria}

The microwave melter is a design based on the principle of "Brewsters Angle". That is, for microwave fields polarized perpendicular to the surface of the glass, the microwave energy is completely transmitted into the surface without reflection when the angle of incidence is equal to Brewsters angle ${ }^{7}, \theta_{B}$, where

$$
\theta_{B}=\tan ^{-1} \sqrt{\varepsilon},
$$

where $\theta_{B}$ is measured from a normal to the glass surface and

$$
\varepsilon=\varepsilon^{\prime}-j \varepsilon^{\prime \prime},
$$


where $\varepsilon^{\prime}$ and $\varepsilon^{\prime \prime}$ are the real and imaginary parts of the dielectric constants for the dielectric material, respectively. Both $\varepsilon^{\prime}$ and $\varepsilon^{\prime \prime}$ are temperature dependent and some data exists on how they vary with temperature ${ }^{8}$. A wide range of temperatures are encountered from room temperature start-up $\left(\sim 25^{\circ} \mathrm{C}\right)$ to vitrification $\left(\sim 900-1200^{\circ} \mathrm{C}\right)$, and therefore some empirical testing is required to optimize the microwave performance. For typical dielectric parameters, $\theta_{B}$ varies between $65-80^{\circ}$ from the normal to the glass surface, depending upon temperature. The amount of microwave attenuation per unit length, $\alpha$, is primarily controlled by the ratio $\varepsilon^{\prime \prime} / \varepsilon$, called the "loss tangent" or " $\tan \delta$ ", and is given by

$$
\alpha=\frac{\sqrt{2} \pi}{\lambda_{0}} \sqrt{\sqrt{1+\left(\frac{\varepsilon^{\prime \prime}}{\varepsilon^{\prime}}\right)^{2}}-1},
$$

where $\lambda_{o}$ is the free space wavelength. The microwave fields decay exponentially as

$$
E(z)=E_{0} e^{-\alpha z},
$$

where $E(z)$ is the microwave electric field as a function of distance, z, and $E_{o}$ is the electric field intensity at $z=0$. We expect the surface attenuation to be high enough to limit microwave penetration to a few $\mathrm{cm}$ when the melt temperature is above $900^{\circ} \mathrm{C}$. Molten glass has a moderately low electrical resistivity $(.1-40 \Omega-\mathrm{cm})$. In order to get good penetration by the microwave energy, a low microwave frequency of $915 \mathrm{MHz}$ was chosen. The pool of glass is inclined to the axis of the waveguide by an angle of $20^{\circ}$ to taper the microwave absorption in the glass, thus minimizing the reflected microwave power. The melter design was tested at low microwave power levels using a microwave network analyzer to determine the optimum angles for minimizing reflections. From these initial tests the drain holes were located. After initial high power testing the level of glass in the melter was reduced by using a drain located lower into the glass pool. It was desirable to deposit the microwave energy in as shallow a volume as possible for good microwave penetration and yet have enough glass to minimize the reflected power. To reduce the likelihood of arcing, a gap between the top wall of the waveguide and the melt is desirable.

\section{Melter Description}

The microwave melter was powered by a $75-\mathrm{kW}, 915-\mathrm{MHz}$ microwave generator. The waveguide transmission system connecting the generator to the melter consists of a dualdirectional coupler, a fiberglass window and several waveguide bends. Air and dry nitrogen were introduced between the window and the melter to keep the waveguide clean. Forward and reflected power were measured by a dual-directional coupler with forward and reflected power monitors. The difference in forward and reflected power is simply the net power $(\mathrm{Pn})$ absorbed by the melter. Since all the internal metal surfaces of the melter have very low microwave losses compared to glass, almost all of the net 
microwave power is absorbed by the glass. The melter is shown schematically in Fig. 1. The melter is standard WR 975 rectangular waveguide with inside dimensions of $24.7-\mathrm{cm}$ wide by 12.4-cm high. The waveguide is fabricated from $6.4-\mathrm{mm}$ thick Inconel alloy and the waveguide axis is inclined $20^{\circ}$ to the horizontal. The glass is in direct contact with the Inconel walls. The exterior of the melter is covered with $1.27-\mathrm{cm}$ thick fiberboard insulation. Unlike a conventional joule-heated melter, there are no dome heater elements required to jump start the glass heating process since the microwave heating is direct. Also there is no internal refractory insulation. The melter is fed manually through a $10-\mathrm{cm}$ diameter port on the top of the melter through which microwave energy cannot propagate (cut off). The molten glass is drained out through a $1.9-\mathrm{cm}$ drain hole in the bottom of the waveguide. The off-gas system had a condenser and a ventilation system capable of producing a slight negative pressure. The temperature along the outside of the bottom of the waveguide was measured by an array of four type $K$ thermocouples (T1, T2, T3 and T4) located along the centerline of the waveguide. An infrared sensor was mounted along the axis of the waveguide looking at the surface temperature (Tir) of the glass. A video camera and light source also looked along the axis to record the vitrification process.

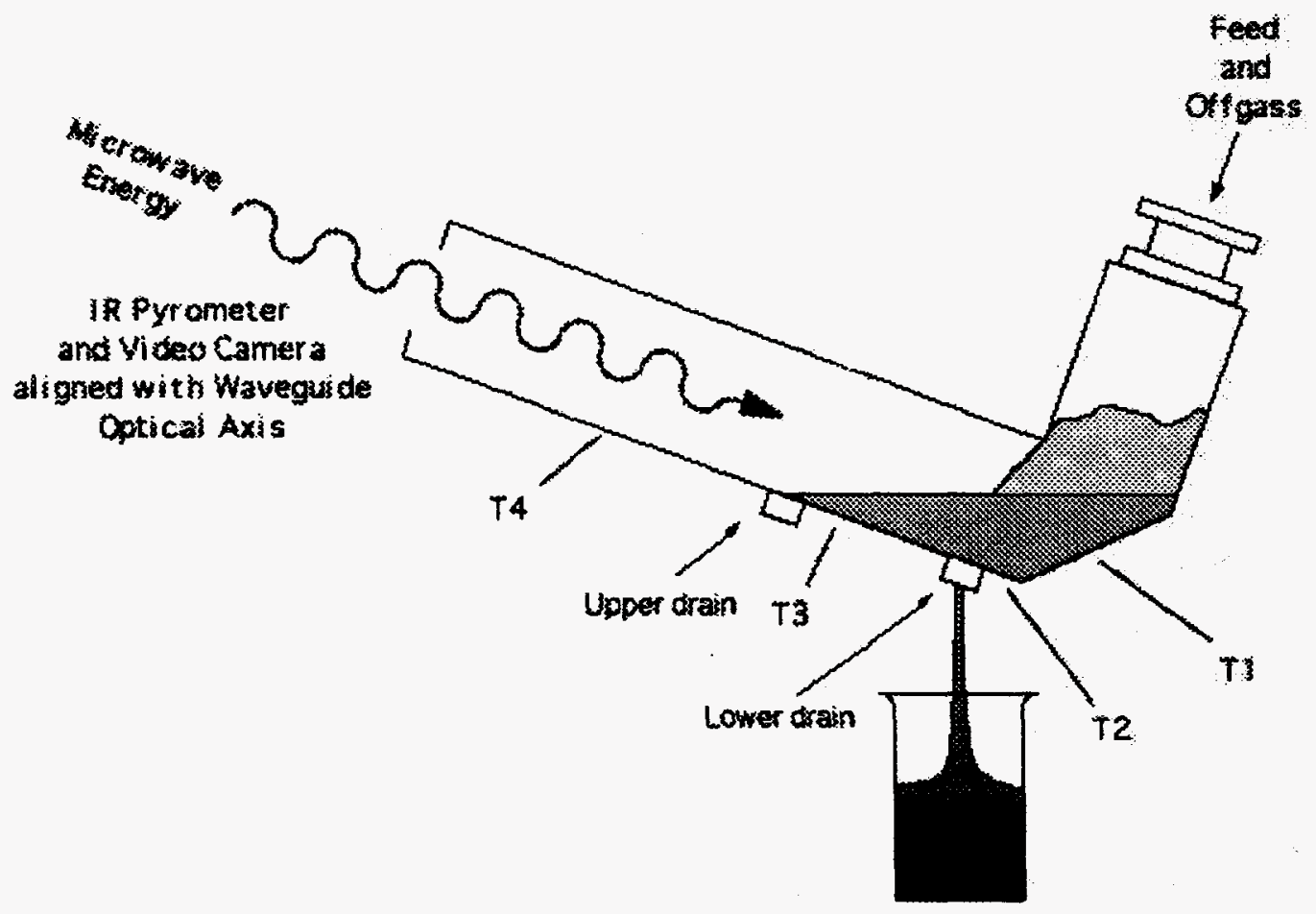

Fig. 1. A cut-away side view of the melter.

Data from the forward and reflected power and the temperature measurements were acquired by a windows-based personal computer running the Labview data acquisition and control software. An overall view of the microwave melter and video monitoring system are shown in Fig. 2. A metal table covered with insulating firebrick supports the melter. A 
section of flexible bellows waveguide (shown in the upper left hand corner of Fig. 2) allows $\pm 5^{\circ}$ of tilt about the $20^{\circ}$ melter angle to adjust glass level.

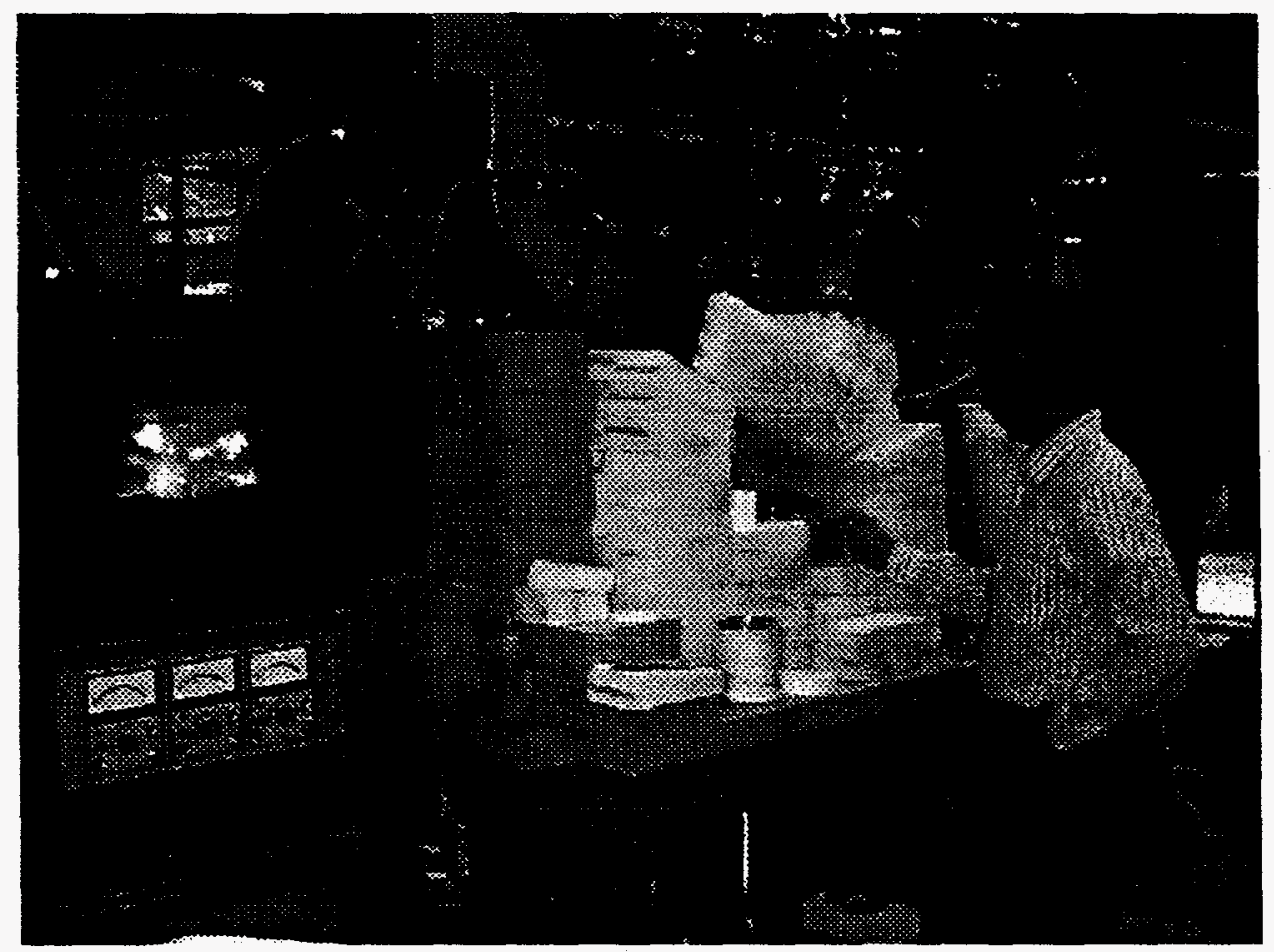

Fig. 2. Overall view of the Microwave Melter and video monitoring system.

\section{Experimental Results}

The authentic sludge is predominantly calcium carbonate, with trace levels of $\mathrm{Mg}, \mathrm{Si}, \mathrm{Al}$, and $\mathrm{Fe}$; the material is nonhazardous by EPA criteria, but is contaminated by low levels of $\mathrm{Sr}^{90}$ and $\mathrm{Cs}^{137}$. A non-radiological surrogate has been formulated according to the following table for treatability studies ${ }^{9}$. The amount of frit (either sand or fly ash) required to produce a suitable glass waste form is also shown in the Table. Borax is added as a fluxing agent to lower the meiting temperature of the simulated filtercake sludge and glass frit mixture. One gram of surrogate dry solids yields $0.34 \mathrm{~g}$ of calcined waste solids. For the surrogate and frit formulated in the table, the waste loading (calcined oxide basis) is approximately $44.7 \mathrm{wt} \%$. Compared to a composite sample of as-stored wet filtercake, 1 $\mathrm{g}$ of calcined waste (or $2.24 \mathrm{~g}$ of glass product) is equivalent to an original volume of 3.34 $\mathrm{cm}^{3}$ wet sludge. These 'figures of merit', together with measurement of the glass product density, allow estimation of achievable volume reduction for the treated waste. The volume reduction for the output waste form over the volume of the input filtercake sludge is estimated to be approximately 4.1 to 1 . 
TABLE

Preparation of Simulated ORNL filtercake sludge (as dry solids) and frit

\begin{tabular}{|c|c|c|}
\hline \multicolumn{2}{|c|}{ Compound } & \multirow{2}{*}{ Weight \% } \\
\hline Surrogate & Frit & 34.8 \\
\hline $\mathrm{CaCO}_{3}$ & & 6.8 \\
\hline $\mathrm{SiO}_{2}$ & & 4.2 \\
\hline $\mathrm{MgO}$ & & 2.4 \\
\hline $\mathrm{Fe}_{2} \mathrm{O}_{3}$ & & 1.8 \\
\hline $\mathrm{Al}(\mathrm{OH})_{3}$ & & 33.5 \\
\hline & $\mathrm{SiO}_{2}$ (sand) or fly ash* & 16.5 \\
\hline & $\mathrm{Na}_{2} \mathrm{~B}_{4} \mathrm{O}_{7} \cdot 10 \mathrm{H}_{2} \mathrm{O}$ (Borax) & \\
\hline
\end{tabular}

* Tennesse Valley Authority Kingston, Tennessee Steam Plant

Fig. 3 shows the operational microwave melter with glass pouring into a $400 \mathrm{ml}$ beaker. No freeze valves were used on the melter since the glass flow can be stopped in a matter of seconds by removing the microwave power. This is due to the small thermal mass of the microwave melter.

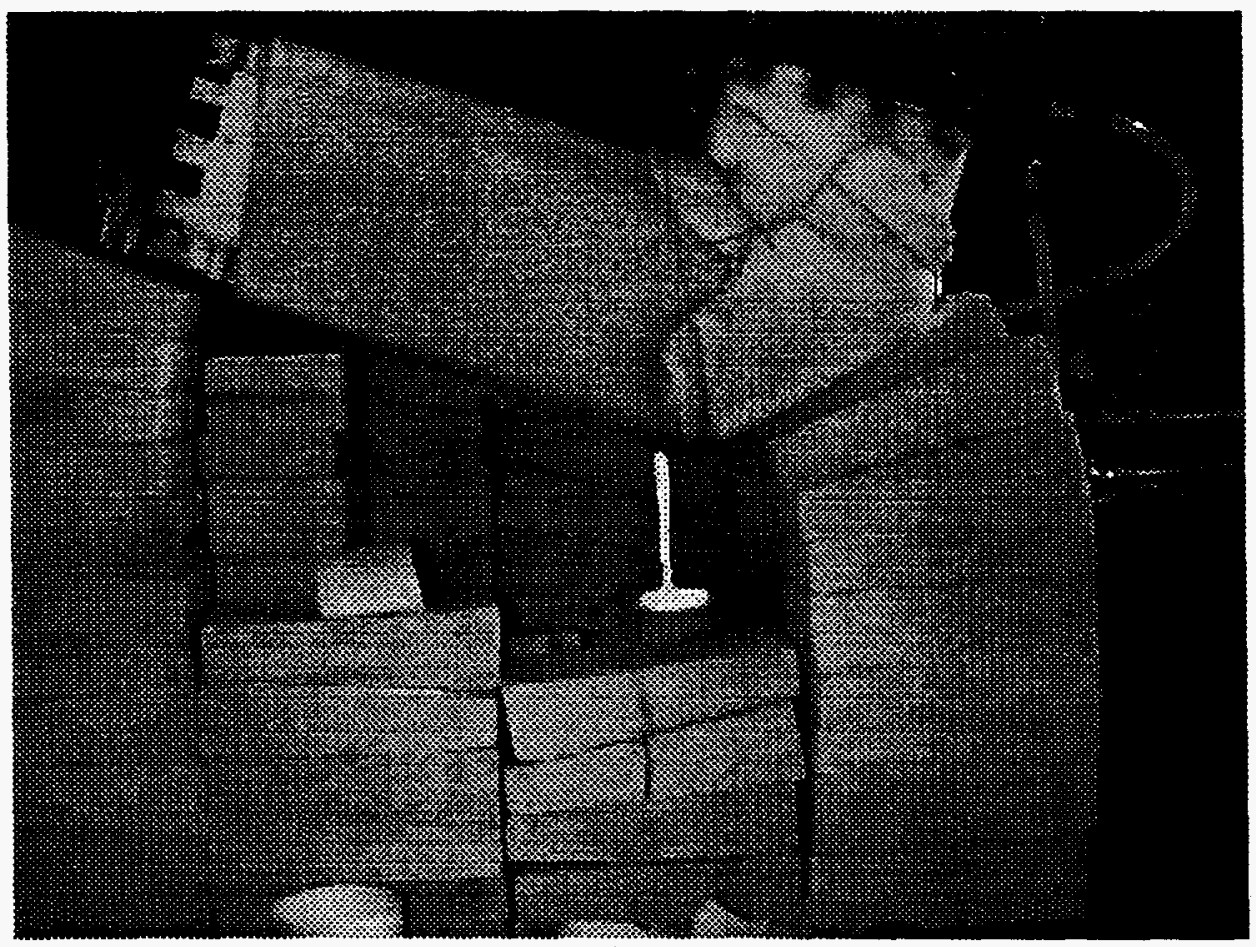

Fig. 3. Side view of the Microwave Melter pouring vitrified glass into a $400 \mathrm{ml}$ beaker.

A plot of the data for this pour is shown in Fig. 4. Because of the intense direct microwave heating of the waste, the outside temperature of the melter never exceeded 
$900^{\circ} \mathrm{C}$ for this experimental run, even though the pouring temperature of the molten glass is about $950^{\circ} \mathrm{C}$. The average glass output rate per unit of absorbed microwave power was measured to be $2.8 \mathrm{~kg} / \mathrm{kW}$-hr for the $275 \mathrm{ml}$ pour. This figure is in fair agreement with simple heat capacity calculations which neglect heat losses. The melter has an unusually small thermal mass and can be cycled on and off much more quickly than a conventional joule-heated melter. The internal construction of the microwave melter is simple and inexpensive when compared to the complex insulation and electrode structure of jouleheated melters. This should result in much lower melter replacement costs. The infrared surface temperature is very low because the cold frit has covered the surface of the molten glass.

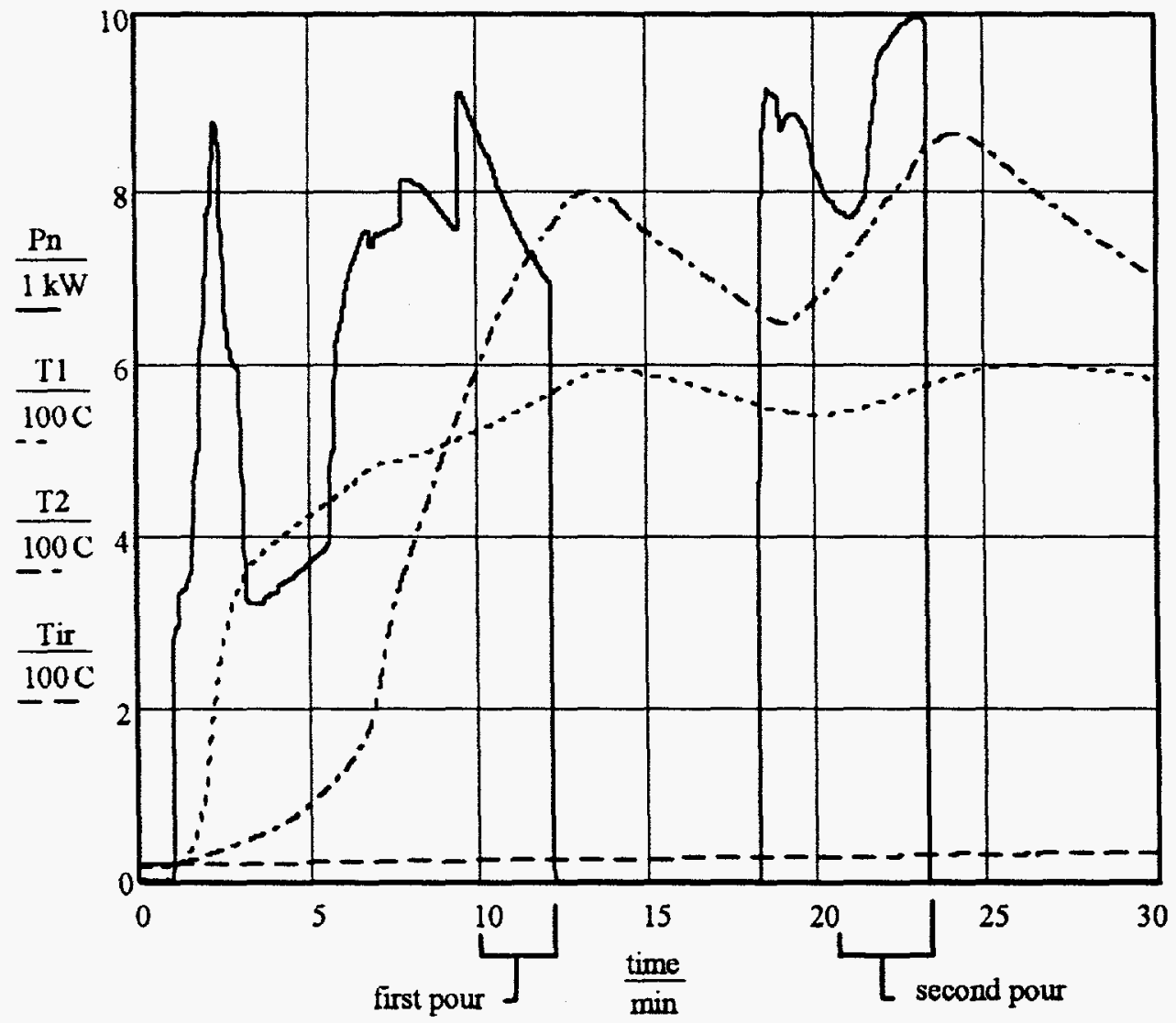

Fig. 4. Plot of absorbed power and temperatures versus time from a cold start.

A second pour was made at 20 minutes into the run. Fig. 5. shows some samples of the vitrified surrogate waste forms (left) and input waste form (right). The wastes have a glassy appearance with a final density of approximately $2.7 \mathrm{~g} / \mathrm{cm}^{3}$. Fig. 6 shows the results of an longer run where $5 \mathrm{~L}$ of glass was poured into a $18.4-\mathrm{cm}$ diameter $304-\mathrm{L}$ stainless steel beaker. Studies are being performed on these wastes and will be presented at the meeting along with glass samples and a video of the microwave melter in operation. 


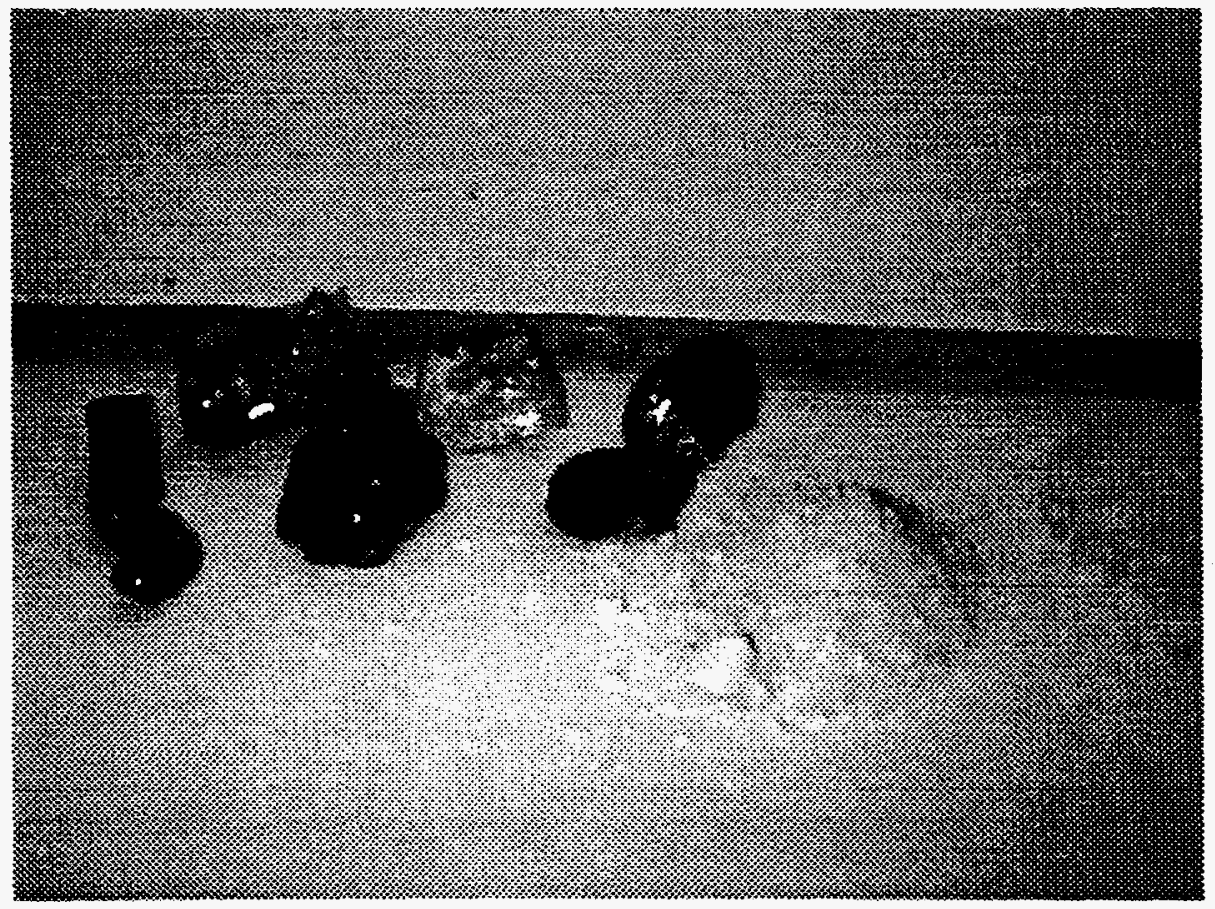

Fig. 5. Vitrified surrogate waste forms (left) and input waste form (right).

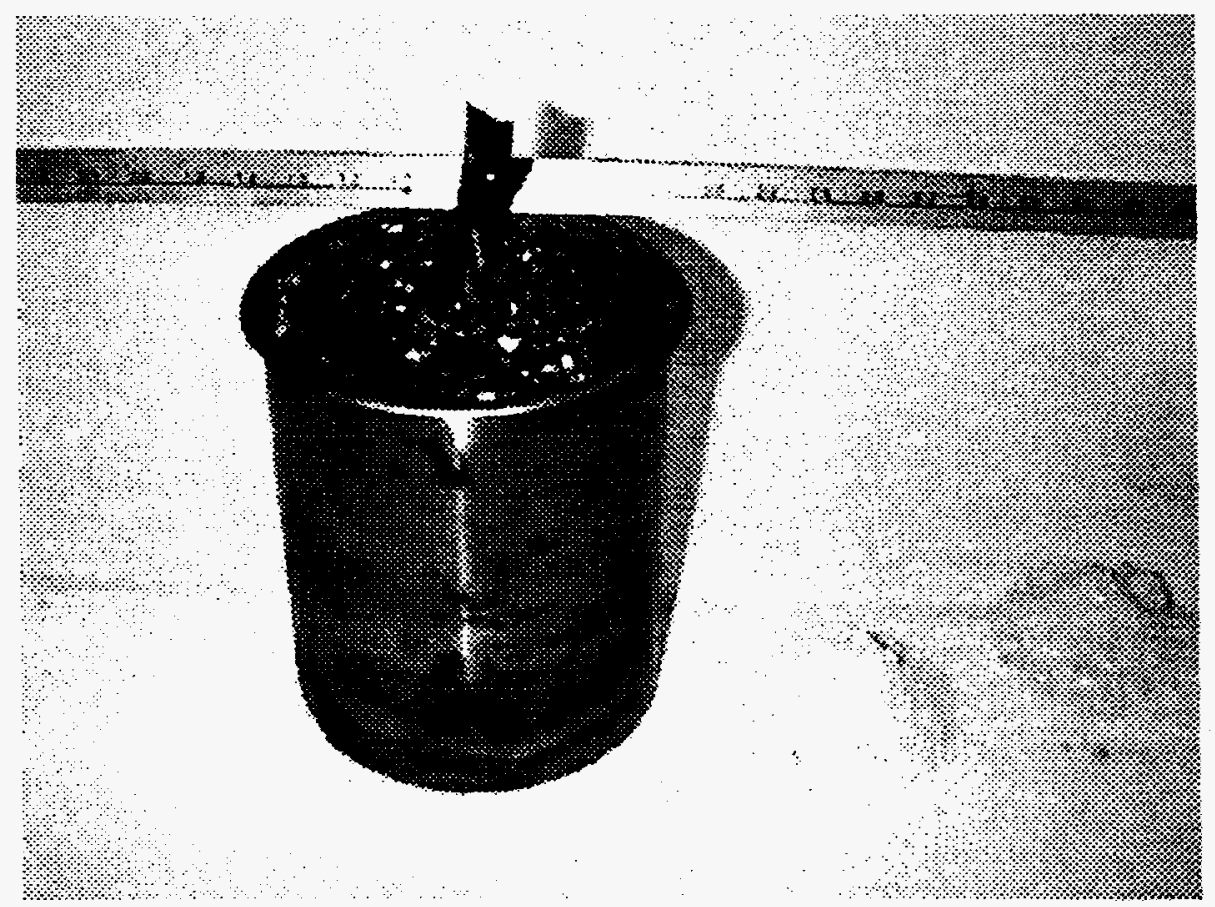

Fig. 6. A 5-L volume of waste glass poured into a stainless steel beaker (left) and input waste form (right). 


\section{Conclusions}

ORNL is involved in the development of high-power microwave heating systems for the vitrification of DOE radioactive sludges and solids. Compared to conventional jouleheated melters, microwave melters offer very simple design, fast startup and shutdown, potentially less expensive melter replacement, and small equipment size. Design criteria for a continuous microwave vitrification system capable of processing a surrogate filtercake sludge representative of a typical waste-water treatment operation are discussed. An operational $915-\mathrm{MHz}, 75-\mathrm{kW}$ prototype microwave melter is described along with some early experimental results that demonstrate a 4 to 1 volume reduction of a surrogate ORNL filtercake sludge.

\section{References}

1. W. A. Ross, M. R. Elmore, C. L. Warner, L. J. Wachter, W. L. Carlson, and R. L. Devries, "Locations, Volumes, and Characteristics of DOE's Mixed Low-Level Wastes," in R. G. Post and M. E. Wacks (eds.), "Waste Management '92," Symposium on Waste Management at Tucson, Arizona, March 1-5, 1992, pp. 1127-1135.

2. H. T. Lee, W. D. Bostick, et al., "Treatability Studies of Low-Level Contaminated Water Softening Sludge," report in preparation (1995).

3. R. G. Baxter, "Design and Construction of the Defense Waste Processing Facility Project at the Savannah River Plant," Proc. 15th Symp. on Waste Management (Waste Management '89), Tucson, AZ, Feb.26-Am. Nucl. Soc., Mar. 2, 1989.

4. G. D. DelCul, W. D. Bostick, R. E. Adamski, W. A. Slover, P. E. Osborne, R. I. Fellows and T. L. White, "Solidification of Waste Sludges Using Microwave Heating," 1994 International Incineration Conference, Houston, TX, pp. 615-620, 1994.

5. T. L. White, "Microwave Applicator for In-Drum Processing of Radioactive Waste Slurry," U. S. Patent 5,324,485, June, 1994.

6. M. S. Morrell, W. H. Hardwick, V. Murphy, and P. F. Wace, "A Pilot Plant Demonstration of the Vitrification of Radioactive Solutions Using Microwave Power," Nuclear and Chemical Waste Management, Vol. 6, pp. 193-195,1986.

7. S. Ramo, J. R.. Whinnery and T. V. Van Duzer, Fields and Waves in Communication Electronics, John Wiley \& Sons, New York, pp. 363-364, 1967.

8. A. R. Von Hippel, Dielectric Materials and Applications, John Wiley \& Sons, New York, pp. 400-404, 1954. 
9. W. D. Bostick, D. P. Hoffmann, R. J. Stevenson, A. A. Richmond, "Surrogate Formulations for Thermal Treatment of Low-Level Mixed Waste, Part IV: Wastewater Treatment Sludges," Report DOE/MWIP-18, Martin Marietta Energy Systems, Oak Ridge, Tennessee, January 1994. 


\section{DISCLAIMER}

This report was prepared as an account of work sponsored by an agency of the United States Government. Neither the United States Government nor any agency thereof, nor any of their employees, makes any warranty, express or implied, or assumes any legal liability or responsibility for the accuracy, completeness, or usefulness of any information, apparatus, product, or process disclosed, or represents that its use would not infringe privately owned rights. Reference herein to any specific commercial product, process, or service by trade name, trademark, manufacturer, or otherwise does not necessarily constitute or imply its endorsement, recommendation, or favoring by the United States Government or any agency thereof. The views and opinions of authors expressed herein do not necessarily state or reflect those of the United States Government or any agency thereof. 